\title{
Methane Hydrates: More Than a Viable Aviation Fuel Feedstock Option
}

Robert C. Hendricks

Glenn Research Center, Cleveland, Ohio 


\section{NASA STI Program . . . in Profile}

Since its founding, NASA has been dedicated to the advancement of aeronautics and space science. The NASA Scientific and Technical Information (STI) program plays a key part in helping NASA maintain this important role.

The NASA STI Program operates under the auspices of the Agency Chief Information Officer. It collects, organizes, provides for archiving, and disseminates NASA's STI. The NASA STI program provides access to the NASA Aeronautics and Space Database and its public interface, the NASA Technical Reports Server, thus providing one of the largest collections of aeronautical and space science STI in the world. Results are published in both non-NASA channels and by NASA in the NASA STI Report Series, which includes the following report types:

- TECHNICAL PUBLICATION. Reports of completed research or a major significant phase of research that present the results of NASA programs and include extensive data or theoretical analysis. Includes compilations of significant scientific and technical data and information deemed to be of continuing reference value. NASA counterpart of peer-reviewed formal professional papers but has less stringent limitations on manuscript length and extent of graphic presentations.

- TECHNICAL MEMORANDUM. Scientific and technical findings that are preliminary or of specialized interest, e.g., quick release reports, working papers, and bibliographies that contain minimal annotation. Does not contain extensive analysis.

- CONTRACTOR REPORT. Scientific and technical findings by NASA-sponsored contractors and grantees.
- CONFERENCE PUBLICATION. Collected papers from scientific and technical conferences, symposia, seminars, or other meetings sponsored or cosponsored by NASA.

- SPECIAL PUBLICATION. Scientific, technical, or historical information from NASA programs, projects, and missions, often concerned with subjects having substantial public interest.

- TECHNICAL TRANSLATION. Englishlanguage translations of foreign scientific and technical material pertinent to NASA's mission.

Specialized services also include creating custom thesauri, building customized databases, organizing and publishing research results.

For more information about the NASA STI program, see the following:

- Access the NASA STI program home page at http://www.sti.nasa.gov

- E-mail your question via the Internet to help@sti.nasa.gov

- Fax your question to the NASA STI Help Desk at 301-621-0134

- Telephone the NASA STI Help Desk at 301-621-0390

- Write to: NASA Center for AeroSpace Information (CASI) 7115 Standard Drive Hanover, MD 21076-1320 


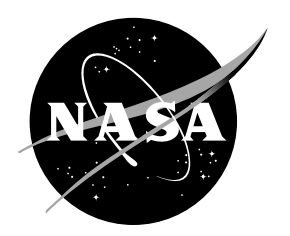

\section{Methane Hydrates: More Than a Viable Aviation Fuel Feedstock Option}

Robert C. Hendricks

Glenn Research Center, Cleveland, Ohio

Prepared for the

Fifth International Energy Conversion Engineering Conference and Exhibit (IECEC) sponsored by the American Institute of Aeronautics and Astronautics St. Louis, Missouri, June 25-27, 2007

National Aeronautics and

Space Administration

Glenn Research Center

Cleveland, Ohio 44135 
This report contains preliminary findings, subject to revision as analysis proceeds.

This work was sponsored by the Fundamental Aeronautics Program at the NASA Glenn Research Center.

Level of Review: This material has been technically reviewed by technical management.

Available from

NASA Center for Aerospace Information

7115 Standard Drive

Hanover, MD 21076-1320
National Technical Information Service 5285 Port Royal Road Springfield, VA 22161 


\title{
Methane Hydrates: More Than a Viable Aviation Fuel Feedstock Option
}

\author{
Robert C. Hendricks \\ National Aeronautics and Space Administration \\ Glenn Research Center \\ Cleveland, Ohio 44135
}

\section{Summary}

Demand for hydrocarbon fuels is steadily increasing, and greenhouse gas emissions continue to rise unabated with the energy demand. Alternate fuels will be coming on line to meet that demand. This report examines the recovering of methane from methane hydrates for fuel to meet this demand rather than permitting its natural release into the environment, which will be detrimental to the planet. Some background on the nature, vast sizes, and stability of sedimentary and permafrost formations of hydrates are discussed. A few examples of the severe problems associated with methane recovery from these hydrates are presented along with the potential impact on the environment and coastal waters. Future availability of methane from hydrates may become an attractive option for aviation fueling, and so future aircraft design associated with methane fueling is considered.

\section{Introduction}

The impact of unabated anthropogenic energy demand is reflected in an enhanced demand for hydrocarbon fuel sources, which in turn impacts our planetary environment in terms of global warming through emissions. Competing biotic and abiotic theories of hydrocarbon fuel (oil) production place reserves at finite and limited to within perhaps 50 to 100 years up to no finite bounds, yet oil demand outpaces production and prices continue to soar. With increased demand for hydrocarbon fuels, alternate fuels based on bio (natural crops), coal, natural gas, and methane hydrates are, or will be, coming on line to meet that demand, yet at a higher cost to the consumer and to the planet. In all cases, the greenhouse gas emissions continue to rise unabated with energy demand. Likewise evidence of glaciered ice melts attests to rise in ocean temperatures and ocean levels, which in turn impacts the stability of vast sources of methane hydrates and the coastal industrial complex. The unabated release of methane (10 to 20 times more detrimental as a greenhouse gas than $\mathrm{CO}_{2}$ ) sequestered in these hydrates could impact the planet to the point of extinction of life as we understand it. Considering the predicted Earth thermal events, the stability of methane hydrates, and the impact of methane on the environment, the question is not will this methane be released, but when. It is suggested in this report that enhanced efforts be placed on a comprehensive program to locate, assess, and recover the sequestered methane at surface levels to meet the energy demand rather than permitting natural release into the environment.

This report provides some background on the nature and vast sizes of sedimentary and permafrost formations of hydrates and discusses their stability. A few examples of the severe problems associated with methane recovery from these hydrates are presented along with the potential impact on the environment and costal waters.

Current aviation fueling trends are concentrated on drop-in fuels, that is, those satisfying Jet A specifications. However future availability of methane from hydrates may become attractive, and so future aircraft design associated with methane fueling is considered. Still, the world energy producers and consumers are encouraged to turn to the Sun and learn to capture, store, condition, and transmit that energy to meet energy needs and to maintain planetary stability. 


\title{
Energy Consumption and Emissions
}

World fuel (energy) consumption is increasing linearly and potentially exponentially, leading to unsatisfied demands with high prices and shortages. The 2003 world energy consumption was about 420.98 Quads ${ }^{1}$ (Q). The U.S. energy consumption was 98.31 Q, accounting for nearly a quarter of the world consumption (ref. 1). Of this, over 60 percent of this energy is attributed to oil and gas (ref. 2).

For hydrocarbon fuels to continue meeting the energy demands for transportation, land-based power production, and manufacturing, there will be increases in emissions of $\mathrm{CO}_{2}$, NOx, hydrocarbon particulate matter, and particulates in general (ref. 3). Emissions records of (a) $\mathrm{CO}_{2}$ (ref. 4), (b) NOx (ref. 5), (c) sulphates (ref. 6), and (d) methane (ref. 7) over a millennium are marked by an exponential rise upon the onset of the widespread use of petroleum.

These energy demands are outpacing gains in engine efficiency and decreases in fuel burn. The result is higher cost fuels, increased emissions and greenhouse gases (GHG), and anthropogenic effects.

\section{Biotic and Abiotic Oil and Natural Gas Potential}

Projections of "peak oil" are based on biotic oil deposits less than $6 \mathrm{~km}$ deep, and those of abiotic (abiogenic) oil are based on formations in the Earth's mantle at depths below $20 \mathrm{~km}$, claiming continuous formation without limits (refs. 8 and 9). The key issues are drilling, logging, and recovery methods at extreme depths.

\section{Biotic or "Fossil" Oil}

Biotic oil production is waning even in the midst of rising fuel prices, signaling to many the arrival of "peak oil.” World oil projections as per Campbell’s peak oil study (ref. 9) imply diminishing of long-term supply and the end of "cheap oil.” This by no means signals a lack of fuels or energy, but recovery potential and expense become the issues.

Synthetic fuels can be derived from coal and natural gas using the well-known Fischer-Tropsch (F-T) process (ref. 10) or by modifications to current refinery techniques (Prof. Harold H. Schobert, 2006, Energy Institute, Pennsylvania State University, University Park, PA, 16802-5000, schobert@ems.psu.edu, personal communication). These fuels, with some further refining or additives, have the potential to be transportation and aviation fuels. Biofuels—such as ethanol and biodiesel—are also emerging for aviation applications but will require further refining (ref. 11).

\begin{abstract}
Abiotic Oil
Even in the face of depleting oil supplies and high energy prices, there is re-emerging evidence that oil is abiotic of origin and is continually being formed deep within the Earth (ref. 12). These concepts are given credence by NASA scientists in studies showing that abundant methane of a nonbiologic nature is found on Saturn's giant moon Titan (ref. 13), a finding that validates the contention that oil is not a fossil fuel. Further, the impact of the 4.5-bya (billion years ago) comet 9P Tempe1 showed an abundance of hydrocarbon $\mathrm{CH}-\mathrm{X}$ in the post-impact spectra, whereas it was only marginally available in the pre-impact spectra. Abundant water and $\mathrm{CO}_{2}$ appeared in both spectra with the configuration constituency of a "dirt ball” (ref. 14).

There is also laboratory evidence of hydrocarbon generation of oil at intense pressures (refs. 8, 15, and 16). In 1951 Nikolai Kudryavtsev initiated the abiotic theory of oil formation, which is now attributed to Russian and Ukranian scientists. This abiogenic theory was perhaps first cited by Mikhailo Vasilyevich Lomonosov in the year 1757 with notable proponents such as Mendeleev (ref. 12) and Berthelot (refs. 16 and 17).
\end{abstract}

${ }^{1}$ Conversion: bbl-oil equivalent is $5.4 \times 10^{6} \mathrm{Btu} / \mathrm{bbl}$ and 1 Quad = $1 \mathrm{Q}=10^{15} \mathrm{Btu}$; thus, $1 \mathrm{Q}=185.185 \times 10^{6} \mathrm{bbl}$-oil equivalent. 


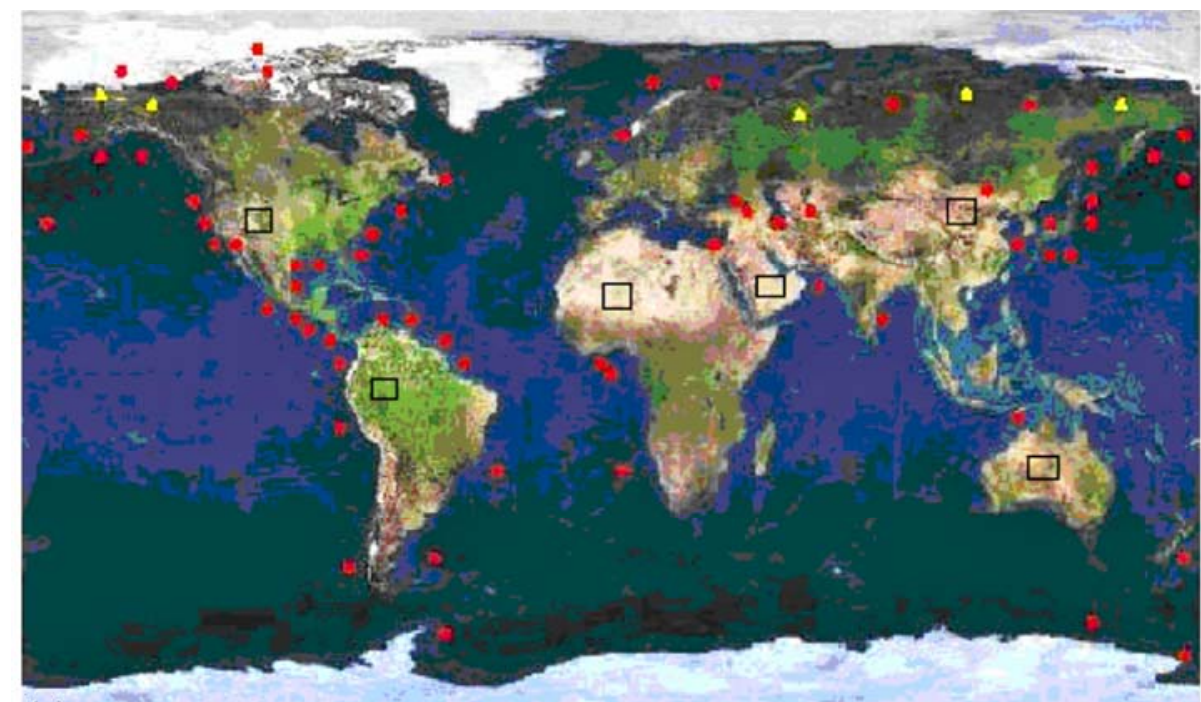

(a)

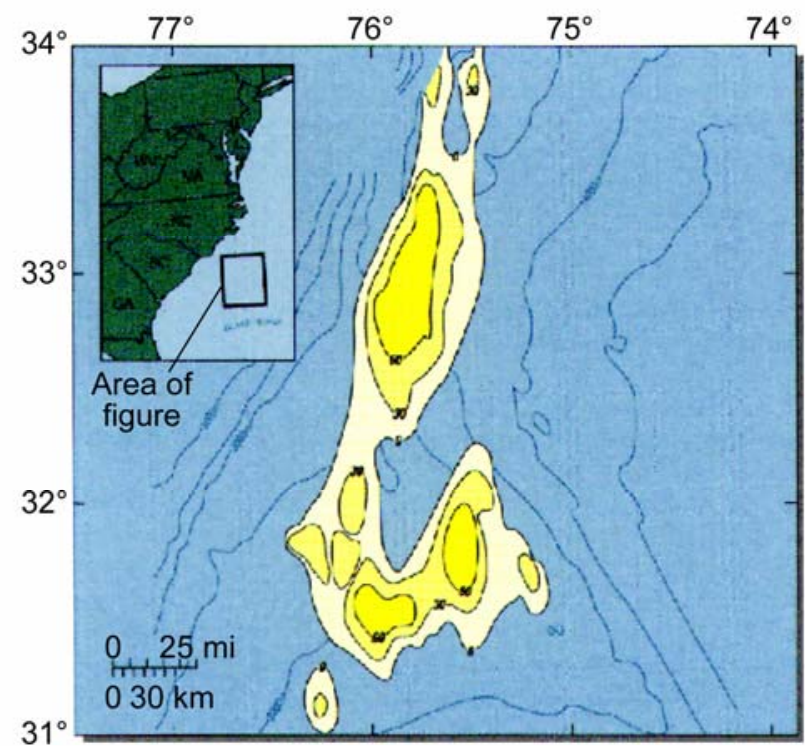

(b)

Figure 1.-Methane hydrate locations. (a) Global gas (methane) hydrate formations indicated by red dots (from ref. 21); potential drilling sites are indicated by yellow dots; and Smalley's likely areas for massive solar power generation (ref. 22) are indicated by open boxes. (b) Blake Ridge area, North Carolina and South Carolina coasts, showing location and inferred thickness (in meters) of hydrates (from ref. 23).

Abiotic oil sources are at geological depths of over $20 \mathrm{~km}$, and there are formidable problems associated with locating these formations and recovering the generated oil and gas at these great depths even when using nontraditional methods. Progress is being made in Russia, however, with drillings sites at the Caspian Sea region, Western Siberia, and the Dneiper-Donets Basin (ref. 18).

Much is being discovered and considered; discussions are found in the free encyclopedia (ref. 16).

Kenney et al. (ref. 19) wet 99.9 percent pure $\mathrm{FeO}$ and $\mathrm{CaCO}_{3}$ with triple-distilled water in a test cell to demonstrate abiotic genesis of petroleum hydrocarbons at the high pressures (to $50 \mathrm{kbar}$ ) and temperatures (to $1500{ }^{\circ} \mathrm{C}$ ) characteristically found deep within the Earth's mantle. Below 10 kbar only methane was present, but heavier hydrocarbons began to form above $30 \mathrm{kbar}$, and at $50 \mathrm{kbar}$ and $1500{ }^{\circ} \mathrm{C}$ 
"the system spontaneously evolved methane, ethane, $n$-propane, 2-methylpropane, 2,2-dimethylpropane, $n$-butane, 2-methylbutane, $n$-pentane, 2-methylpentane, $n$-hexane, and $n$-alkanes through $\mathrm{C}_{10} \mathrm{H}_{22}$, ethene, $n$-propene, $n$-butene, and $n$-pentene in distributions characteristic of natural petroleum.”

\section{Methane Hydrates}

Clathrates are compounds where molecules of one substance enclose a different "guest" molecule. Methane hydrate is an example of this: water molecules form a cage around a methane gas molecule (loosely, water plus swamp gas at high pressure and low temperature) (ref. 18). Details of the methane hydrate compound - its structure and formations - are found in the appendix. It is notable because it appears in abundance in ocean depths and permafrost. This reserve could be one of our energy sources, or it could become the bane of the world.

Discovered in 1810 by Sr. Humphrey Davy, methane hydrates $\left(\mathrm{CH}_{4} \cdot 5.75\left(\mathrm{H}_{2} \mathrm{O}\right)\right)$ appear naturally as well as cemented in sediments. They were a nuisance in the 1930s, forming blockages in gas pipelines at low temperatures. Other common clathrates include those with ethane, propane, isobutane, normal butane, nitrogen, carbon dioxide, and hydrogen sulfide; although methane hydrate is the most abundant (ref. 20).

Moreover, these hydrate sources of natural gas appear in abundance in permafrost and ocean slopes throughout the world (fig. 1(a)). Large hydrate deposits are found located about the American continents (fig. 1(b)) and in the permafrost regions of Alaska, Canada, and Russia. Hydrates are even found in some deep lakes such as Baikal (located in Siberia near the Mongolian border) and perhaps Lake Superior in the United States.

Methane hydrate and gaseous methane deposits are huge. Estimates by the Department of Energy suggest 0.2 million trillion cubic feet (ref. 24) (i.e., $0.2 \times 10^{18} \mathrm{ft}^{3} \approx 0.2 \times 10^{21} \mathrm{Btu}=0.2 \mathrm{MQ}$ ). To place this in perspective, at the projected natural gas consumption for the year 2025 of 156.2 trillion cubic feet, this represents over a millennium's gas supply and nearly two-thirds of a millennium's total energy at this rate of consumption. These estimates can be an order of magnitude less, as noted in the MH21 project gas estimate of 100 years (ref. 25). The difficulties arise in safe, cost-effective production while sustaining seafloor stability and understanding how these assets will effect climate change and the global carbon cycle.

The gas-rich sediments that usually cement the hydrates are not stable when (1) the pressure falls, (2) the temperature rises, or (3) they are acted upon by salts. As a consequence, the known methods attempted for methane recovery include thermal stimulation, depressurization, and chemical stimulation using brines and alcohols.

Hydrate formations are also being investigated as potential sequestration methods for long-term storage of $\mathrm{CO}_{2}$. However, the issues of thermal and pressure stability as well as sea-floor landslides are common to both methane production from the hydrates as well as long-term storage of hydratesequestered $\mathrm{CO}_{2}$ (refs. 25 to 27).

\section{A Case for Methane Recovery From Hydrates}

Whether abiotic or "fossil," "cheap oil” is probably history, and although methane hydrates abound, methane recovery will also be expensive. However, there is a major incentive to advance methane recovery-global warming.

The role of methane hydrates in greenhouse gas (GHG) formation is a major concern. Methane is 10 to 20 times more detrimental as a GHG than is $\mathrm{CO}_{2}$. Further, since the beginning of the industrial age, there has been a rapid rise in atmospheric methane as well as other GHGs through natural and anthropogenetic causes (refs. 28 and 29). How are methane hydrates destabilized to release methane gas? 

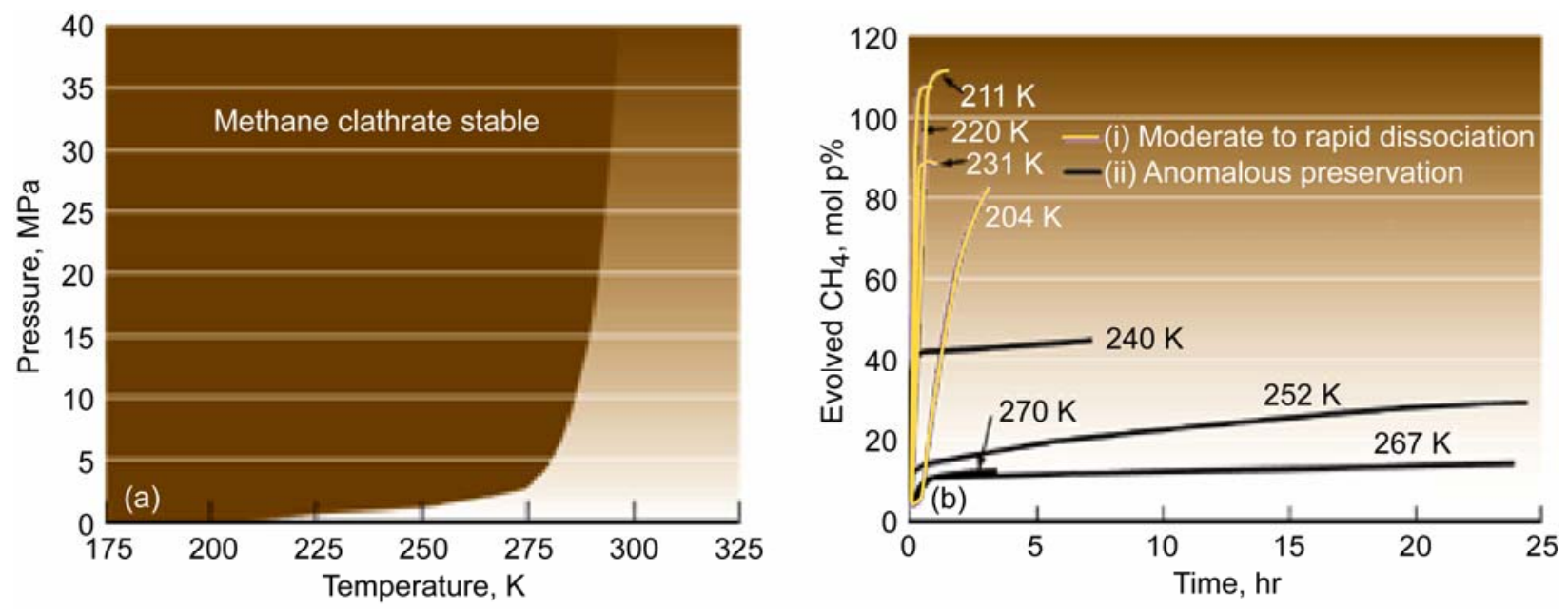

Figure 2.-Stability region for methane hydrates (from ref. 30). (a) Pressure versus temperature curve. (b) Dissociation curve illustrating methane release over time at various temperatures, where the hydrates underwent either (i) slow cooling and decompression or (ii) rapid decompression at selected temperatures.

\section{Thermal and Pressure Effects}

Thermal dissociation and rapid depressurization represent two potential methods for gas recovery from methane hydrates (fig. 2). However, the process can be complex. Mixtures do not behave as singlecomponent fluids. The thermal stability is illustrated in figure 2(a) and more complex behavior in figure 2(b). Here pressurized methane hydrate samples were decompressed to $0.1 \mathrm{MPa}$ by (i) slow cooling and pressure change and (ii) rapid pressure change at selected temperatures. All hydrates quickly decomposed into ice and gas except scenario (ii) labeled “anomalous preservation,” where decomposition took up to 25 hours over the temperature range 270 to $240 \mathrm{~K}$.

Equally so, they also represent natural paths for spontaneous release of large quantities of methane gas-which humanity seeks to avoid.

\section{Climate and Environmental Effects}

As stated prior, methane hydrates are unstable when the temperature rises or the pressure falls. Global warming, while a political "hot potato," is at a critical turning point between rapid and natural temperature rise with time as pointed out by Dr. James Hansen (fig. 3). The outcome can be very diverse. The upper locus represents the business as usual scenario, and the lower locus represents natural events that occur in the life of planet Earth. The issue depicted in the figure is not whether the ocean thermal temperatures will exceed those necessary to maintain methane hydrate stability, but when.

During the Pliocene period (5.3 to 1.8 million years ago (mya)), about 3 mya, Earth was 2 to $3{ }^{\circ} \mathrm{C}$ ( 3.5 to $5.5^{\circ} \mathrm{F}$ ) warmer, and the sea level was about $25 \pm 10 \mathrm{~m}(80 \pm 30 \mathrm{ft})$ higher than today. Estimates are that if the glaciered ice on Greenland melted, the sea level could rise $7 \mathrm{~m}(20 \mathrm{ft})$. The point is that if our planet experienced $\mathrm{a}+2{ }^{\circ} \mathrm{C}\left(3.5^{\circ} \mathrm{F}\right)$ thermal change, the sea level could be much higher than it is today, which implies that sea-level rise will become a major issue (ref. 29). Many of the world's commercial and industrial centers would then be beneath coastal waters-more devastating than the United States's Hurricane Katrina or the Sumatra Indonesia 9.0 earthquake and tsunami (Dec. 26, 2005). Several key low-elevation airports could be endangered, such as New Orleans Louis Armstrong (4 ft), Miami International (10 ft), John F. Kennedy International (13 ft), Washington Ronald Reagan National (16 ft), Newark Liberty (18 ft), and Boston Logan (19 ft). Much of the sea, glycophyte, and halophyte food sources are located within coastal plains. 


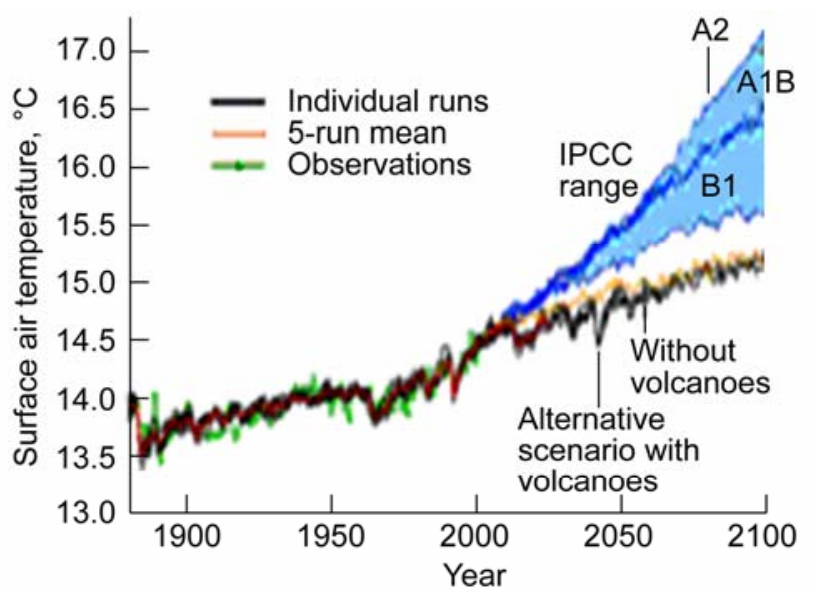

Intergovernmental Panel on Climate Change (IPCC) scenarios (from ref. 31):

A2: represents heterogeneous world with regional development similar to "business as usual."

A1B: represents improved but balanced utilization of fossil and nonfossil energy sources

B1: represents world population peaks midcentury then declines with rapid change toward a service and information economy with clean, efficient technologies.

Alternative scenarios represent additional $\mathrm{CO}_{2}$ forcing of $\sim 1.5 \mathrm{~W} / \mathrm{m}^{2}$ by 2100 .

Figure 3.-Twenty-first century global warming outcomes from Hansen's model (ref. 28).

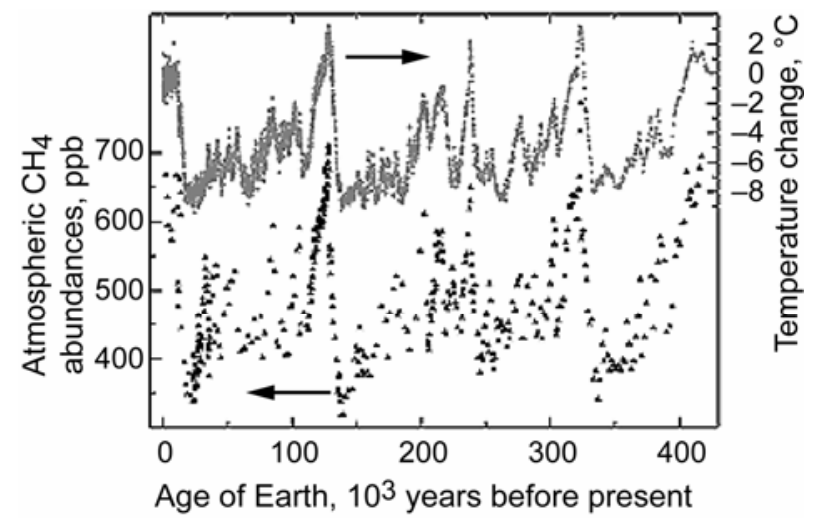

Figure 4.-Earth sedimentary methane and temperature change (from ref. 32).

Sea-level rise will also wreak havoc with physical property and standards that are referenced to sea level standard conditions as standard temperature and pressure (STP). World metrology standards would require revisions resulting in threats to world commerce much more severe than that posed by Y2K.

Spectra of worldwide Paleocene sediments (56 to 65 mya) show prominent negative shifts in carbon, implying a methane abundance. These methane shifts are characterized by climate thermal changes (fig. 4). In terms of geological time, these are rapid fluctuations. Ocean bottom warming of $4{ }^{\circ} \mathrm{C}$ accompanying a rapid shift in carbon- 13 could have engendered a catastrophic release of carbon-12 from methane hydrates. A global temperature maximum occurred about 55.5 mya.

Unabated natural release of methane gas from hydrates within the shallows of the mid-Atlantic potentially could exacerbate tropical storms that devastate the islands and coastal regions of Central America and the United States (refs. 33 and 34). Destruction of sea-bed pipelines and off-shore drilling rigs attest to how these storms (e.g., Katrina) disturb both the ocean floor temperature and structure (including slides (ref. 35)), which in turn destabilize the hydrate formations to further release methane gas. 
With the potential hydrate instabilities as the oceans warm up, spontaneous release of large reserves of methane gas can be anticipated as illustrated in figure 3. The figure illustrates possible global warming scenarios modeled by Hansen (ref. 28). Three Intergovernmental Panel on Climate Change (IPCC) scenarios (from ref. 31) are modeled: A2, representing "business as usual”; A1B, representing balanced utilization of fossil and nonfossil energy sources; and B1, representing a world population peak midcentury then decline with rapid change toward an economy with clean technologies. Scenarios A2 and A1B mimic emissions over the past $10 \mathrm{yr}$ and show increased $\mathrm{CO}_{2}$ emissions at 2 percent/yr over the next $50 \mathrm{yr}$. Alternative scenarios were also modeled, and these show a slow decline in emissions if the additional $\mathrm{CO}_{2}$ forcing is $\sim 1 \mathrm{~W} / \mathrm{m}^{2}$ by 2050 and $\sim 1.5 \mathrm{~W} / \mathrm{m}^{2}$ by 2100 . The climate mode sensitivity of $\sim 2.7^{\circ} \mathrm{C}$ for $\mathrm{CO}_{2}$ doubling is consistent with paleoclimate data and other models. Simulations are consistent with 1880 to 2003 observations keyed to ocean heat storage. If the climate thermal changes follow Hansen's upper locus in figure 3, it is questionable if humanity or other living matter can survive, as neither can convert methane gas to oxygen. If, however, the process is slow as per Hansen's lower locus, then it would seem expedient that humanity seek to recover and use methane gases that would most likely otherwise be released due to thermal instability.

This issue does not seem to have an option. The recovery of unstable hydrate sources of methane gas from the ocean and permafrost that can be converted to useful energy (work) will prevent subsequent release into the environment. Consuming the gas before spontaneous release from the hydrate sources will help offset climate changes through anthropogenic or natural evolution of planet Earth. Simultaneous sequestering of $\mathrm{CO}_{2}$ and replacing the methane in these hydrates will not only aid in offsetting the imminent climate changes, but will maintain the stability of the seafloor and permafrost structures. Simultaneous progress must be made to shift toward solar energy sources and reduce per capita energy consumption through more efficient power and energy systems: a long-term but expedient roadmap to survival.

\section{Methane Hydrates as a Fuel Source}

These "rocks" can be a source of energy; they burn (fig. 5), reminding one of the old miners acetylene lamp powered from calcium carbide and water, which create acetylene.

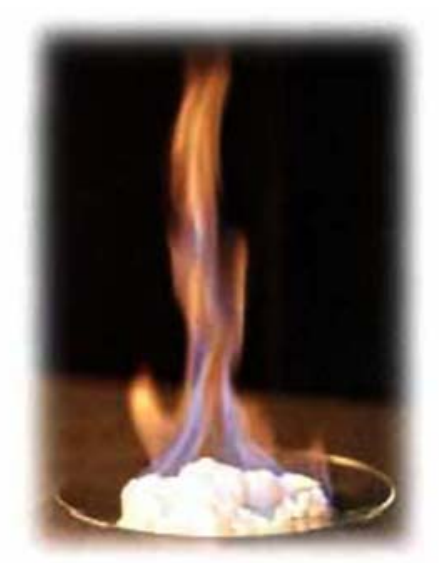

Figure 5.-Burning of natural methane hydrate (taken at the Department of Energy, from ref. 25). 


\section{Recovery From Methane Hydrates}

As a source of fuel, locating and verifying methane hydrate deposits is difficult even with today's three-dimensional seismic mapping, secondary recovery methods, and horizontal drilling techniques. Still, Diaconescu et al. provide some insights (ref. 36):

(1) Geothermal gradients limit hydrates to $<1000$ m of sedimentary section.

(2) Pore water salinity is important in controlling GHSZ (gas hydrate stability zone).

(3) Minimum predicted water depth is $150 \mathrm{~m}$, and maximum predicted depth of hydrate zone is $1350 \mathrm{~m}$.

(4) Geological interests include (a) drilling hazards (for trapped gas), (b) fuels potential, and (c) its role in global climate change.

Mi et al. mapped seismic profiles (ref. 37) to $1150 \mathrm{~m}$, interpreting velocity changes as indicative of hydrate concentration. These profiles show that

(1) Hydrate is found in sediment pores

(2) Hydrate stiffens the sediment substrate

(3) This hydrate dome seals and traps gases beneath the BSR (bottom simulating reflector)

\section{Hydrate Leakage}

Methane gas leakage up through pores in the sediment rock could have caused plugging of the pores, forming hydrate domes. Similar ice plugs are found in gas pipelines at low temperatures and are a nuisance.

Another consideration is whether the methane source is from a biotic oil source or directly from abiotic seepage from sources deep within the Earth's mantle. The abundance may imply the latter.

\section{Methane Recovery From Hydrates}

The process of recovering methane from these hydrates is quite difficult. As sedimentary hydrates can potentially trap high-pressure gas and become unstable, drilling several hundred meters into potentially explosive gas fields is risky (refs. 27, 38, and 39). Further, drilling and recovery could destabilize sedimentary hydrate deposits, triggering major submarine landslides like those that occurred off the coast of Norway some 8200 years ago forming the Storegga ridge (refs. 35 and 38).

Three common recovery methods, (1) depressurization, (2) thermal fluxing, and (3) salts injection, are being considered either individually or in combination. Each cause decomposition of the hydrate. Mining, drilling, or otherwise agitating the sediment for release of the hydrate-bound gases, as noted, is risky, and sudden releases of large volumes of gas can destroy the recovery system and endanger global climate health. While several gas hydrate recovery systems are proposed, those involving ocean hydrate recovery are most at risk, while permafrost recovery less so. Syntroleum Corporation has a recent patent on an ocean recovery system (ref. 39) (fig. 6).

Basically the system consists of a recovery ship and a ship transporting liquid natural gas and liquefied petroleum gas. The recovery system involves a hood where the hydrates are mined by any or all of the three basic recovery methods, including hydrate melting via electrical current (ref. 40), which appears difficult as it implies very high voltage. Seo and Lee (ref. 26), Ross and Proenza (ref. 27), and the MH21 project (Ichikawa and Yonezawa, ref. 25) are investigating hydrate recovery systems that also inject $\mathrm{CO}_{2}$ to re-form the sediment bearing the hydrates to stabilize the formation and mitigate seafloor shifting and landslides. 


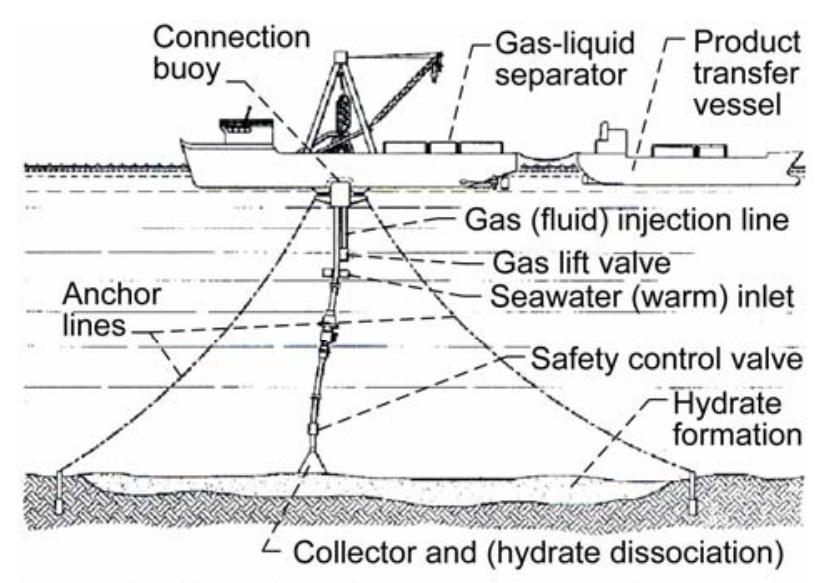

Figure 6.-Syntroleum Corporation system for methane gas recovery from hydrates (from ref. 39).

\section{Airplane Design Issues}

As aviation fuels, cryogens pose a paradigm shift in design and handling. Safe transfer and use of liquid cryogens is not easy or all that conventional, yet cryogenic rocket propulsion systems were used by the Germans in WWII and have been used by NACA/NASA since the mid-1950s: for example, liquid oxygen and liquid ammonia for the $\mathrm{X}-15$. Airplane designs for cryogens methane $(111.55 \mathrm{~K}$ and $0.4226 \mathrm{gm} / \mathrm{cm}^{3}$ at boiling point) and hydrogen $\left(20 \mathrm{~K}\right.$ and $\left.0.071 \mathrm{gm} / \mathrm{cm}^{3}\right)$ involve new tanks, engine systems, good thermal management, and safe handling. Hydrogen is not a forgiving fluid if handled improperly, and methane can be worse since it will not dissipate as readily as hydrogen. Also, hydrogen must be stored as parahydrogen; otherwise the boiloff rates can be excessive.

Consequently, comparisons of $\mathrm{CH}_{4}$ - and $\mathrm{H}_{2}$-fueled airplanes with Jet-A-fueled aircraft show significant changes in aircraft design. For example, hydrogen on an energy-per-unit-weight basis is 0.36 that of Jet A, yet on an energy-per-unit-volume basis the ratio is 4.2 (ref. 11). As cryogens, the fuels can no longer be readily stored in the wings, and the fuselage, external (or pod), or multiple fuselage tanks become most practical. Unitary fuselage tanks impose on the passengers who must be fit between or below fuel storage tanks. This poses crash safety problems from the cold fluid rupture, ensuing cryogenic burns, and suffocation. In this respect, hydrogen is the better fluid. Although it requires storage at colder temperatures, it is light, boils easily, and dissipates readily, and the Leidenfrost phenomenon better protects warmer surfaces. In accidents large volumes of cold gas will cause suffocation, and means to protect against these issues must be provided. Oxygen masks may not be a good solution as hydrogen and oxygen are very reactive - often uncontrollably — when united.

Recent advances in gel foams (aerogels, refs. 41 and 42) permit conformal, yet structural-bearing insulation that may enable new forms of insulated tanks for aviation use. While most designs are centered on conventional heavy cryogenic tanks, it may be possible to certify low-pressure, minimum-slosh, lowboiloff cryogenic methane or hydrogen tanks using these foams. Still, nonconventional cryogenic fuel tanks for aviation will require significant crash-fire and impact testing prior to even considering commercial aviation application.

Based on the NASA Challenger incident, good cases can be made for separable external or nonpassenger fuselage tanking systems. Accidents and failures happen, and for a world fleet of over 30000 (ref. 43) with a 1-in-a-million reliability for each component in a 10000 -component system1 percent of which are critical—one can expect 300 failures, 3 of which are critical. The larger question of what reliability is acceptable requires a lot of data and very good modeling to be answered.

Consequently, where aviation is concerned there rapidly becomes a case for the use of gas reformation with methane from hydrates and other sources to produce gas-to-liquid F-T fuels simulating Jet A fuels. These new fuels or blends with biokerosene could result in enhanced in-flight safety with 
minimum disruption on logistics and infrastructure. Still, the use of hydrocarbon fuels is at the expense of the environment, although it is less so for biofuels.

\section{Concluding Remarks}

While methane can be a viable aviation fuel, the issue of recovery from methane hydrate does not seem to hold an option. In time, spontaneous natural release will occur, and the following protocol is suggested:

(1) Locate unstable sources of methane hydrates that can be converted to useful energy (work). Then, release and capture the methane before it is released spontaneously due to climate changes. Stabilize the formation by sequestering $\mathrm{CO}_{2}$.

(2) Decrease the use of oil ("fossil" or abiotic) and synthetic hydrocarbon energy sources, replacing these by captured or otherwise produced methane gas. Natural gas re-forming followed by the Fischer-Tropsch or other processes and necessary refining can be used to derive high hydrocarbons as desirable, including sources for medicines, plastics, and dense fuels for aviation.

(3) Plant and nurture trees and other green living matter, such as algae and halophytes, on a global scale. This provides both renewable fuel sources and the oxygen necessary to balance the environment.

In conjunction with these, the following actions are also suggested:

(4) Move toward efficient solar energy collection, conversion, storage, and transmission systems.

(5) Monitor the shoreline upon global climate changes, and respond accordingly.

(6) In general, reduce per capita energy consumption through more efficient power and energy systems, including natural ventilation, light, water usage, and organic subsistence.

\section{References}

1. International Energy Outlook 2006. Energy Information Administration, DOE/EIA-0484(2006), 2006. http://www.eia.doe.gov/oiaf/ieo/oil.html Accessed July 31, 2007.

2. Hendricks, R.C., et al.: Global Energy and Aviation Concerns. 2005 NASA Seal/Secondary Air System Workshop, NASA/CP—2006-214383/VOL1, 2006, pp. 79-105.

3. Intergovernmental Panel on Climate Change: Climate Change 2001: The Scientific Basis. http://www.grida.no/climate/ipcc_tar/wg1/index.htm Accessed July 31, 2007.

4. Intergovernmental Panel on Climate Change: Climate Change 2001: The Scientific Basis. Section 3.2.3.2, fig. 3.2. http://www.grida.no/climate/ipcc_tar/wg1/105.htm\#fig32 Accessed July 31, 2007.

5. Intergovernmental Panel on Climate Change: Climate Change 2001: The Scientific Basis. Section 4.2.1.2, fig. 4.2. http://www.grida.no/climate/ipcc_tar/wg1/fig4-2.htm Accessed July 31, 2007.

6. Intergovernmental Panel on Climate Change: Climate Change 2001: The Scientific Basis. Section 5.2.5, fig. 5.4. http://www.grida.no/climate/ipcc\%5Ftar/wg1/180.htm\#fig54 Accessed July 31, 2007.

7. Intergovernmental Panel on Climate Change: Climate Change 2001: The Scientific Basis. Section 4.2.1.1, fig. 4.1. http://www.grida.no/climate/ipcc_tar/wg1/fig4-1.htm Accessed July 31, 2007.

8. Free Energy Technology News and Directory. http://freeenergynews.com/ Directory/Theory/SustainableOil/index.html Accessed July 31, 2007.

9. Uppsala Hydrocarbon Depletion Study Group. http://www.peakoil.net/uhdsg/Default.html Accessed July 31, 2007.

10. Fischer-Tropsch Process. Wikepedia. http://en.wikipedia.org/wiki/Fischer-Tropsch_synthesis Accessed July 31, 2007. 
11. Daggett, D., et al.: Alternative Fuels and Their Potential Impact on Aviation. NASA/TM-2006214365 (ICAS-2006-5.8.2), 2006.

12. Mendeleev, D.: L'origine du petrole. Revue Scientifique, 2e Ser., VIII, 1877, pp. 409-416.

13. Rainbows on Titan. Science@NASA. http://science.nasa.gov/headlines/y2005/25feb_titan2.htm Accessed July 31, 2007.

14. A’Hearn, M.F., et al.: Deep Impact: Excavating Comet Tempel 1. Science, vol. 310, no. 5746, 2005, pp. 258-264.

15. Kenney, J.F., et al.: Dismissal of the Claims of a Biological Connection for Natural Petroleum. Energia, vol. 22, no. 3, 2001, pp. 26-34. http://www.gasresources.net/DisposalBioClaims.htm Accessed July 31, 2007.

16. Abiogenic Petroleum Origin. Wikipedia. http://en.wikipedia.org/wiki/Abiogenic_petroleum_origin Accessed July 31, 2007.

17. Kenney, J.F.: Considerations About Recent Predictions of Impending Shortages of Petroleum Evaluated From the Perspective of Modern Petroleum Science. ISSN 1526-5757, 2007. http://www.csun.edu/\%7Evcgeo005/Energy.html Accessed July 31, 2007.

18. Krayushkin, V.A., et al.: The Drilling \& Development of the Oil \& Gas Fields in the DnieperDonetsk Basin. http://www.gasresources.net/DDBflds2.htm Accessed July 31, 2007.

19. Kenney, J.F., et al.: The Evolution of Multicomponent Systems at High Pressures: VI. The Thermodynamic Stability of the Hydrogen-Carbon System: The Genesis of Hydrocarbons and the Origin of Petroleum. Proceedings of the National Academy of Sciences, vol. 99, no. 17, 2002, pp. 10976-10981. www.pnas.org/cgi/doi/10.1073/pnas.172376899 Accessed July 31, 2007.

20. Thomas, Ellen: Clathrates: Little Known Components of the Global Carbon Cycle. http://ethomas.web.wesleyan.edu/ees123/clathrate.htm Accessed July 31, 2007.

21. Future Supply and Emerging Resources-The National Methane Hydrates R\&D Program. National Energy Technology Laboratory. http://www.netl.doe.gov/scngo/NaturalGas/hydrates/databank/ HydLocations.htm Accessed July 31, 2007.

22. Smalley on Energy. SCiSCOOP Science News Forum, Nov. 4, 2004. http://www.sciscoop.com/story/2004/11/3/20322/6497 Accessed July 31, 2007.

23. Gas (Methane) Hydrates_A New Frontier. U.S. Geological Survey, Sept. 1992. http://marine.usgs.gov/fact-sheets/gas-hydrates/title.html Accessed July 31, 2007.

24. Methane Hydrate - The Gas Resource of the Future. U.S. Department of Energy, updated July 11, 2007. http://www.fe.doe.gov/programs/oilgas/hydrates/index.html Accessed July 31, 2007.

25. Ichikawa, Yuichiro; and Yonezawa, Tetsuo: The Outline of the MH21 Program and the R\&D Plan of Methane Hydrate Development System for Offshore Japan. http://www.jdc.co.jp/MH21Outline.pdf Accessed July 31, 2007.

26. Seo, Yu-Taek; Lee, Huen; and Yoon, Ji-Ho: Hydrate Phase Equilibria of the Carbon Dioxide, Methane, and Water System. J. Chem. Eng. Data, vol. 46, 2001, pp. 381-384.

27. Ross, Jake; and Proenza, Yuliana: Methane Hydrates. The Three Questions. http://www.eps.mcgill.ca/ courses/c186-455/SG2004\%20presentations/Methane\%20Hydrates. ppt\#256,1,Methane\%20Hydrates Accessed July 31, 2007.

28. Hansen, James E.: Is There Still Time to Avoid 'Dangerous Anthropogenic Interference' With Global Climate? A Tribute to Charles David Keeling, Presented at the American Geophysical Union, San Francisco, CA, Dec. 2005. http://www.columbia.edu/ jeh1/keeling_talk_and_slides.pdf Accessed July 31, 2007.

29. The Ticking Clock: Greenland Glaciers Melting Twice as Fast as Expected. Solutions, Environmental Defense, vol. 37, no. 3, June 2006.

30. Methane Hydrate: A Surprising Compound. www.llnl.gov/str/Durham.html Accessed July 31, 2007.

31. Intergovernmental Panel on Climate Change. http://www.grida.no/climate/ipcc_tar/wg3/015.htm Accessed Aug. 10, 2007. 
32. Petit, J.R., et al.: Climate and Atmospheric History of the Past 420,000 Years From the Vostok Ice Core, Antarctica. Nature, vol. 399, 1999, pp. 429-436. http://www.grida.no/

climate/ipcc_tar/wg1/fig4-1.htm Accessed July 31, 2007.

33. Dickens, G.R.: Methane Hydrate and Abrupt Climate Change. Geotimes, vol. 49, no. 11, 2004. http://www.agiweb.org/geotimes/nov04/\#features Accessed July 31, 2007.

34. Sever, M.: Beneath the Bermuda Triangle. Geotimes, vol. 49, no. 11, 2004, pp. 34-35. http://www.agiweb.org/geotimes/nov04/\#features Accessed July 31, 2007.

35. Nisbet, E.G.; and Piper, D.J.W.: Giant Submarine Landslides. Nature, vol. 392, 1998, pp. 329-330. http://eprints.rhul.ac.uk/archive/00000013/01/NisbetPiper.pdf Accessed July 31, 2007.

36. Diaconescu, C.C.; Kieckhefer, R.M.; and Knapp, J.H.: Geophysical Evidence for Gas Hydrates in the Deep Water of the South Caspian Basin, Azerbaijan. Mar. Pet. Geol., vol. 18, 2001, pp. 209-221.

37. Mi, Yangpeng, et al.: Vertical Seismic Profiling and Seismic Properties of Gas Hydrate in an Arctic Well. CREWES Research Report, vol. 11, 1999. www-crewes.geo.ucalgary.ca/Reports/ 1999/1999_52.pdf Accessed July 31, 2007.

38. RAND Environmental Game Changers: The Future of Energy and Contamination. http://www.fathom.com/course/10701027/session2.html Accessed July 31, 2007.

39. Agee, Mark A.; Weick, Larry J.; and Agee, Kenneth L.: System and Method for Hydrate Recovery. U.S. Patent 5,950,732, Sept. 14, 1999.

40. Kern, Loyd R.: Method of Producing Oil From a Subterranean Formation. U.S. Patent 3,920,072, Nov. 18, 1975.

41. Meador, Mary Ann B., et al.: Structure-Property Relationships in Porous 3D Nanostructures as a Function of Preparation Conditions: Isocyanate Cross-Linked Silica Aerogels. Chem. Mater., vol. 19, no. 9, 2007, pp. 2247-2260. 10.1021/cm070102p Accessed July 31, 2007.

42. Capadona, Lynn A., et al.: Flexible, Low-Density Polymer Crosslinked Silica Aerogels. Polymer, vol. 47, no. 16, 2006, pp. 5754-5761.

43. Dinell, David: Boeing Forecasts World Aircraft Fleet of 34,000 Within Two Decades. Wichita Business Journal, 2003. http://www.bizjournals.com/wichita/stories/2003/09/15/daily18.html Accessed July 31, 2007.

44. Collett, T.S.: Gas Hydrates as a Future Energy Resource. Geotimes, vol. 49, no. 11, 2004, pp. $24-27$. http://www.agiweb.org/geotimes/nov04/\#features Accessed July 31, 2007.

45. Lubick, N.: Technology: Detecting Marine Gas Hydrates. Geotimes, vol. 49, no. 11, 2004, pp. $28-30$. http://www.agiweb.org/geotimes/nov04/\#features Accessed July 31, 2007. 


\section{Appendix}

Methane hydrate is a solid chemical compound known as a clathrate and in the natural state, looks like ice and is formed at relatively low temperatures and high pressures.

A clatharate is a network of cages of bonded host molecules that enclose guest molecules. The hydrate is commonly used to describe a clathrate where water is the host molecule, and methane hydrate is the case where the guest molecule is gaseous methane. The common form is $\mathrm{CH}_{4} \cdot 5.75 \mathrm{H}_{2} \mathrm{O}$, where 5.75 is the "hydrate number" (fig. 7).

The hydrate number varies by the proportion of the guest molecules that fill the cages. In theory, $1 \mathrm{~m}^{3}$ of methane hydrate dissociates (endothermally) into $0.8 \mathrm{~m}^{3}$ of water and $172 \mathrm{~m}^{3}$ of methane gas (at STP, or atmospheric pressure and $0{ }^{\circ} \mathrm{C}$ ), and the latent heat is about $50 \mathrm{~kJ} / \mathrm{mole}$, which is 1.3 times that of water-ice (ref. 25).

In sediments, the hydrates can become cemented in such as way as to form a rock-like structure (fig. 8), which can be difficult to stabilize. These structures can also dome sources of methane gas and rupture upon attempts to recover or drill. Unstable configurations are known to have caused large landslides off the coast of Norway (ref. 35) and in some cases may have spawned tsunamis. Other forms include hydrates forming in gas-bearing rock.

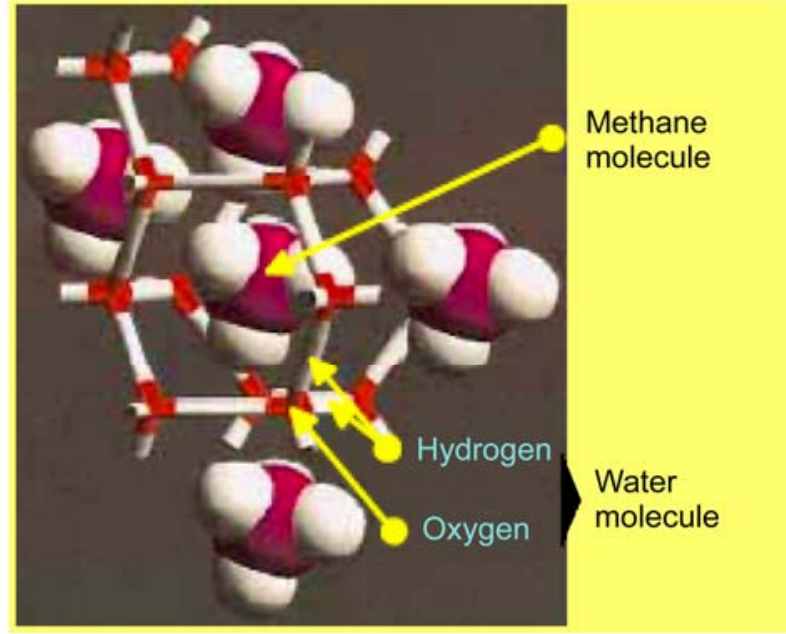

Figure 7.-Structure of common methane hydrate (from ref. 25).

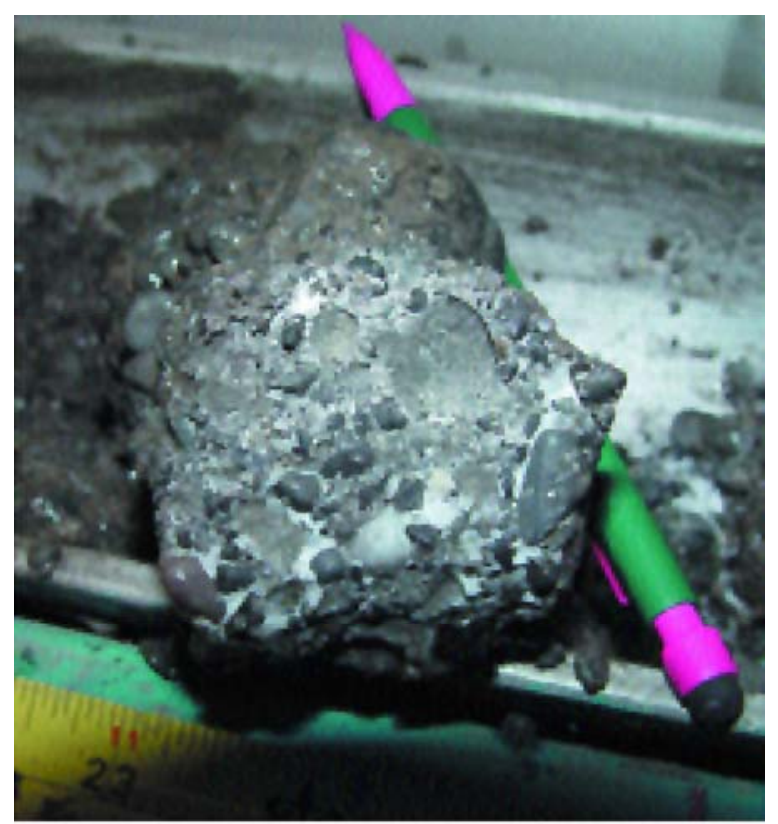

Figure 8.-Arctic gas-hydrate-bearing rock at Mallik site in Canada (from ref. 44). 
Typical methane hydrate formations (fig. 9) are found in (refs. 20 and 27)

(1) Gas hydrate stability zones (GHSZ), which are roughly parallel to land or seafloor surface (which is usually sloped)

(2) Permafrost regions 150 to $2000 \mathrm{~m}$ below surface

(3) Oceanic sediment at least $300 \mathrm{~m}$ deep and at depths below the seafloor 0 to $1100 \mathrm{~m}$

For example, a 50- by 150-km area of Blake Ridge off coast of North and South Carolina has the potential of 70 years U.S. natural gas supply.

Ross and Proenza (fig. 10), Lubick (ref. 45) and others provide illustrations of potential hydrate regions.

The Ross and Proenza conceptual gas hydrate production system (fig. 11) incorporates some conventional mining techniques with $\mathrm{CO}_{2}$ sequestration. Surface seawater, warmer than the seafloor water, is injected into the lower part of the gas hydrate formation, which dissociates the hydrate. The released gas is then piped to the surface while $\mathrm{CO}_{2}$ gas is injected into the $\mathrm{CH}_{4}$-depleted hydrate sediment structure, forming a $\mathrm{CO}_{2}$ hydrate to stabilize the ocean floor.

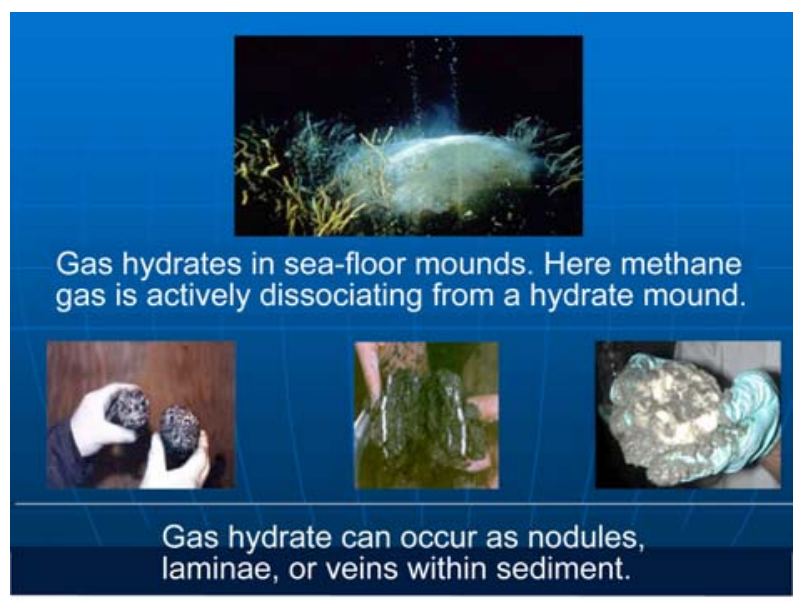

Figure 9.-Typical methane hydrate formations (from ref. 27).

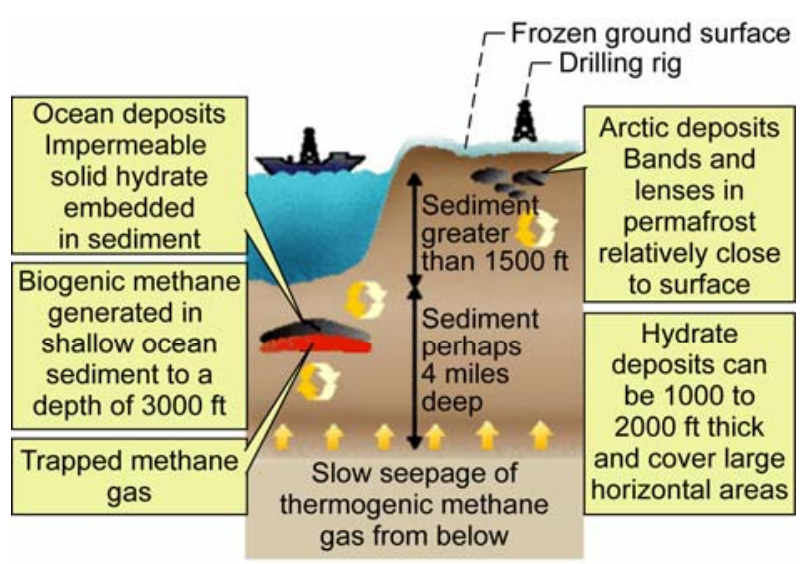

Figure 10.-Potential methane hydrate deposits (from ref. 27).

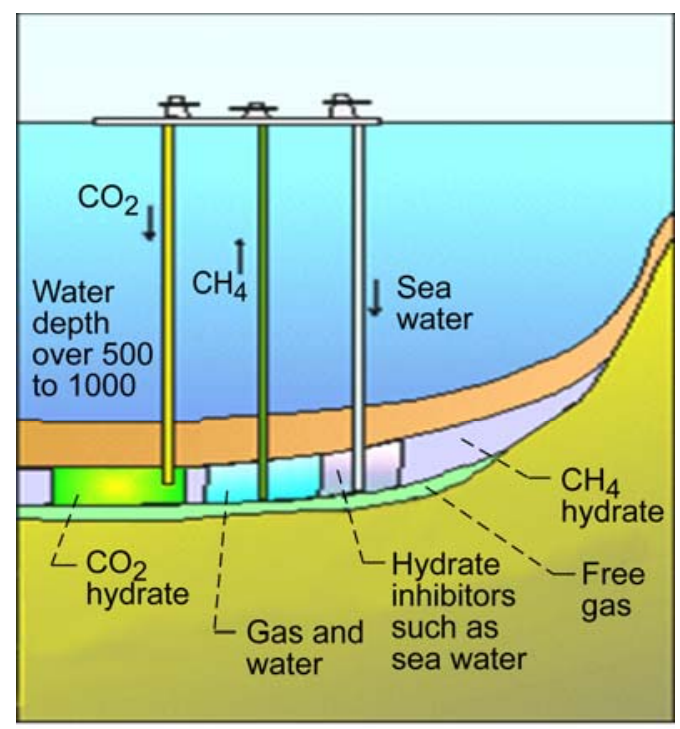

Figure 11.-Potential gas recovery and hydrate stabilization method (from ref. 27). 


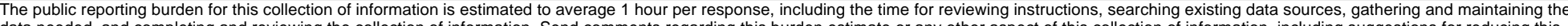

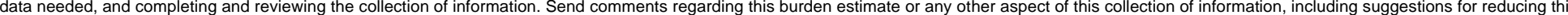

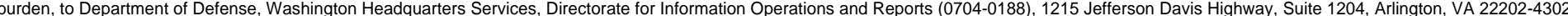

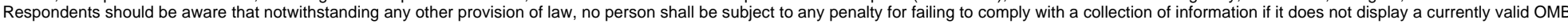
control number.

PLEASE DO NOT RETURN YOUR FORM TO THE ABOVE ADDRESS.

\section{REPORT DATE (DD-MM-YYYY) \\ 2. REPORT TYPE \\ 3. DATES COVERED (From - To)}

01-11-2007

\section{TITLE AND SUBTITLE}

Technical Memorandum

Methane Hydrates: More Than a Viable Aviation Fuel Feedstock Option

5b. GRANT NUMBER

5c. PROGRAM ELEMENT NUMBER

Hendricks, Robert, C.

\section{AUTHOR(S)}

\section{5d. PROJECT NUMBER}

5e. TASK NUMBER

5f. WORK UNIT NUMBER

WBS 561581.02.08.03.16.03

\section{PERFORMING ORGANIZATION}

REPORT NUMBER

E-15975

National Aeronautics and Space Administration

John H. Glenn Research Center at Lewis Field

Cleveland, Ohio 44135-3191

9. SPONSORING/MONITORING AGENCY NAME(S) AND ADDRESS(ES)

National Aeronautics and Space Administration

Washington, DC 20546-0001

\section{DISTRIBUTIONIAVAILABILITY STATEMENT}

Unclassified-Unlimited

Subject Category: 28

Available electronically at http://gltrs.grc.nasa.gov

This publication is available from the NASA Center for AeroSpace Information, 301-621-0390

\section{SPONSORINGIMONITORS ACRONYM(S) \\ NASA \\ 11. SPONSORING/MONITORING REPORT NUMBER \\ NASA/TM-2007-214816; AIAA-2007- 4757}

\section{SUPPLEMENTARY NOTES}

\section{ABSTRACT}

Demand for hydrocarbon fuels is steadily increasing, and greenhouse gas emissions continue to rise unabated with the energy demand. Alternate fuels will be coming on line to meet that demand. This report examines the recovering of methane from methane hydrates for fuel to meet this demand rather than permitting its natural release into the environment, which will be detrimental to the planet. Some background on the nature, vast sizes, and stability of sedimentary and permafrost formations of hydrates are discussed. A few examples of the severe problems associated with methane recovery from these hydrates are presented along with the potential impact on the environment and coastal waters. Future availability of methane from hydrates may become an attractive option for aviation fueling, and so future aircraft design associated with methane fueling is considered.

\section{SUBJECT TERMS}

Alternate fuels; Aviation; Emissions; Methane hydrates; Abiotic oil

\section{SECURITY CLASSIFICATION OF}

a. REPORT

$\mathrm{U}$

\section{LIMITATION OF} ABSTRACT

UU

18. NUMBER
OF
PAGES
20

19a. NAME OF RESPONSIBLE PERSON

STI Help Desk (email:help@sti.nasa.gov)

19b. TELEPHONE NUMBER (include area code) 301-621-0390 

